\title{
The Use of Gadgets As E-Learning Basis during The COVID-19 Pandemic
}

\author{
Winning Amintas Kartika WaruwuSari ${ }^{*}$,Siti Mayang Sari ${ }^{2 *}$, Jalaluddin ${ }^{3}$, Farida Win Sari \\ Manurung ${ }^{4}$, Sukarman Purba ${ }^{5}$, Lambok Pamancar Saragi ${ }^{6}$ \\ $1^{*}$ AKPER Kesdam I/BB Medan \\ ${ }^{2}$ Universitas Bina Bangsa Getsempena Banda Aceh, Indonesia \\ ${ }^{3}$ Universitas Serambi Mekkah, Banda Aceh, Indonesia \\ ${ }^{4}$ SMK Negeri 1 Percut Sei Tuan, Sumatera Utara, Indonesia \\ ${ }^{5}$ Universitas Negeri Medan, Indonesia \\ ${ }^{6}$ Dinas pendidikan Provinsi Sumatera Utara, Indonesia
}

Corresponding authors: Winning Amintas Kartika Waruwu Sari,winningwaruwu95@gmail.com

\begin{abstract}
Since the pandemic started, online learning has been applied to replace the conventional one. Gadgets then become essential tools and the main information source for learning during this time.This study aims to find out the relationship between gadgets and the effectiveness of learning during the COVID-19 pandemic. It focused onthe readiness of digital infrastructure institutions and the readiness of students in online learning activities during the COVID-19 pandemic. A descriptive qualitative approach was used to describe the roles of gadgets as a learning resource to support effective learning and improve learning outcomes, withliterature review related to the topic.
\end{abstract}

Keywords: Gadgets, Effective, Learning Resources, e-Learning

\section{Introduction}

The COVID-19 pandemic has hit various sectors in Indonesia. Not only the economic sector is impacted, but also the tourism, transportation, manufacturing and education sector. The education sector, in specific, is experiencing major changes in the teaching and learning process. Online learning is applied which raises some pros and cons in the society. The application of online learning aims to protect the students and teachers' health. However, concerns appearedwhen the time for onlinelearning was extended because the COVID-19 pandemic is not over yet.

The first concern was aboutgadgets used for online learning. Gadgets are required to follow the virtual learning and do the assignments (Rosiyanti and Muthmainnah, 2018). The second concern was from lecturers who questionedthe effectiveness of online learning in improving the students' learning outcomes. Some subjects, such as Mathematics, Science, Arts, and Sports,may not be delivered properly through online learning. Many lecturers also have limited experiences in using gadgets; thus, their teaching still tends to be manual and less innovative (Rozalia, 2017). There are also concerns about rising internet costs, especially when there are no internet subsidies from the government. Complaints also come from students who have to postpone their research because they cannot visit the research locations to collect data. Consultation with research supervisors is also hampered. As a result, the graduation target is not in line with expectations. These issues thus encourage the author to conduct research to finda relationship between gadgets and the effectiveness of e-learning during the COVID-19 pandemic. 


\section{Method}

This study used a descriptive qualitative approach to describethe relationship between the gadgets and the effectiveness of e-learning. According to some previous journal literature, gadgets are an effective source of learning forthe students. With a descriptive qualitative method based on journal literature, the results of this study will get a synchronous expression between the use of gadgets and learning effectiveness during the COVID-19 pandemic.

\section{Results and Discussion}

\subsection{Learning Resources}

Learning resources are a unified system in which there are components that are related and influence each other. These components are the parts that are in the learning resource itself, (Sudatha et al., 2020). These parts are a unit that is difficult to stand alone even though they may be used separately(Agisti and Zuhri, 2020).

Education in its development is the role of technology which very quickly affects learning resources.Digital used in the past is a type of learning resource designed to be widely used by lecturers, namely limited to makeshift learning facilities (Pertiwi, 2018). The influence of technology is not only on the form and type of learning resources, but also on the components of learning resources (Meilia and Murdiana, 2019).This becomes clear in the designed learning resources, for example, at first we see visual media images in the form of silent films with technological discoveries in the field of recording and then equipped with sound, the use of video is even more practical and easy to use (Ibrahim, 2019).

The effectiveness of e-learning-based learning is still categorized as inefficient due to several patterns and online learning methods that lack the guidance of lecturers as course supervisors (Hikmat et al., 2020).E-learning-based learning resources are available on campuses that do not yet have online learning infrastructure and are forced to conduct lectures online. Some higher education institutions make online facilities to make it easier for lecturers in their teaching captions to provide online learning rooms as media for online learning resources such as classrooms (Gunawan and Sunarman, 2017).

The form of learning resources with information technology that can be used as a learning medium is to use e-learning. E-learning is an innovation that will be used in online learning, not only for learning materials but also changes in various student competencies. The components of the e-learning form are e-learning infrastructure, e-learning systems and applications and e-learning content. The benefits of e-learning for the world of general education, namely: (1) flexibility of place and time, (2) independent learning, (3) cost, (4) flexibility of learning speed, (5) standardization of teaching, (6) effectiveness of learning and teaching, (7) speed distribution, (8) availability on demand, e-learning can be accessed at any time, (9) automation of administrative processes. The e-learning strategy is to support the implementation of a learning process, which is expected to increase students' absorption of the material provided, increase active participation of students, improve students' independent learning abilities, improve material quality (Hartanto, 2016).

Education and training in improving the ability to display information with information technology devices, expanding the teaching and learning process by using the internet, is not only limited to space and time. The e-learning which involves the first four things is analysis, planning, implementation and evaluation. Several logical consequences that occur from online learning resources include (1) students can easily take learning materials anywhere without being limited by space and time; (2) students can easily learn and discuss with experts about the things they are interested in; (3) learning materials can even be easily taken in any corner of the world regardless of where students study. However, these opportunities still face challenges from the aspect of costs, readiness of information 
technology infrastructure, the community, and regulatory support for e-learning including gadgets owned by students and internet facilities and infrastructure, (Divayana, 2017).

\subsection{Gadgets}

Gadgets are educational or learning media(Rosiyanti and Muthmainnah, 2018). Just imagine if there were no gadgets, especially for students or college students. Gadgets as a supporting device in learning can be applied in formal schools(Rozalia, 2017). The resulting impacts are both positive and negative. Gadgets are small electronic devices that have special functions in each type to make work and human needs more practical and efficient(Florida et al.,2012). One of the steps to use network technology and information technology for the development of learning systems in universities is the online lecture system. Students living in remote areas can access courses from leading universities in Indonesia. The object of this research is the website pditt.learning.kemdikbud.go.id. This website was developed by the Indonesian Ministry of Education and Culture. The locus was chosen because the website is the official website of the government in collaboration with several well-known universities in Indonesia, such as the Nusantara University. The results of the study show that the online lecture system has a positive contribution to encourage disparities in the quality of higher education in Indonesia.The indications include: 1) minimizing the limited access to quality higher education 2) bypassing the limitations of facilities which have been considered as one of the barriers to the low quality of higher education, 3) eliminating limited understanding of certain materials, 4) providing broad access to educational resources, especially in leading universities (Mustofa et al., 2019).

The form of information technology that can be used as a learning medium is to use elearning. E-learning is an innovation that will be used in learning, not only for learning materials but also changes in various student competencies. The components of the e-learning form are e-learning infrastructure, e-learning systems and applications and e-learning content. The benefits of e-learning for the world of general education, namely: (1) flexibility of place and time, (2) independent learning, (3) cost, (4) flexibility of learning speed, (5) standardization of teaching, (6) effectiveness of learning. teaching, (7) speed distribution, (8) availability on demand, e-learning can be accessed at any time, (9) automation of administrative processes (Sudatha et al., 2020).

The e-learning strategy is to support the implementation of a learning process, which is expected to increase students' absorption of the material provided, increase their own active participation(Syaparuddin et al., 2018). E-learning can improve students' independent learning abilities, the quality of the materials, education and training, the ability to display information with information technology devices, and the teaching and learning process using the internet, which are not only limited to space and time (Yazdi, 2012).

As for e-learning which involves the first four things, namely analysis, planning, implementation and evaluation (Darmawan, 2014).In conclusion, E-learning is a cheap and easy information and telecommunication technology that will eliminate the limitations of space and time that have limited the world of education. Some of the logical consequences that occur include (1) students can easily take learning materials anywhere without being limited by space and time; (2) students can easily learn and discuss with experts about the things they are interested in; (3) learning materials can even be easily taken in every corner of the world regardless of where students study (Moore et al., 2011). However, these opportunities still face challenges from the aspect of cost, readiness of information technology infrastructure, society, and regulatory support for e-learning(Dwi et al., 2015). 


\subsection{Learning Effectiveness}

The learning system with the online learning system (on the network) is a learning system without face to face directly between lecturers and students but is carried out online using the internet network. Lecturers provide flexibility to students in the process of teaching and learning activities even though students are at home. The solution is that lecturers continue to provide education and guidance by designing learning media as innovations by utilizing online media (Mayang, 2021).

Lecturers can study with students at the same time using groups on social media, such as WhatsApp (WA), Telegram, Instagram, Zoom Meeting Cloud or other media as learning media. Thus, the lecturer ensures that students can take lessons simultaneouslydespite being in different places.Lecturers will gain learning effectiveness if they are able to design and design online learning that is light and effective. Utilizing appropriate online devices or media in accordance with the material taught by the lecturer. Students are expected to be able to manage online learning as effectively as possible which will provide wider opportunities to explore the material to be taught. However, lecturers must be able to limit the scope of the material and choose a suitable application for the learning material and method(Ibrahim, 2019). The creation of the continuity of the benefits of gadgets and the effectiveness of learning is the increase in students' technological literacy which is currently needed, so that increasing digital characters will receive more attention in education(Jalaluddin, 2020).

\section{Conclusion}

It can be concluded that there is a close relationship between gadgets and the effectiveness of online learning. To achieve the effectiveness, both lecturers and students should have sufficient knowledge and experience in using gadgets. These willalso enable easy access tolearning resources available online. Furthermore, lecturers should provide some flexibility to students because online learning constraints are also present on the students' side. To make the learning interesting,lecturers are encouraged todesign innovative learning materials. In addition, universities are also suggested to provide online facilities to facilitatethe teaching and learning process.

\section{References}

Agisti, K.\&Zuhri A. F. (2020). "Peran Jurnalis Dalam Mewartakan Berita Pembelajaran Jarak Jauh Dalam Masa Pandemi Virus Corona Di Indonesia." El Banar: Jurnal Pendidikan, 47-58.

Aprikustianita, R.G., Wiwit, O., \&Susanto, R. (2018). "Identifikasi Cara Belajar Mahasiswa Dalam Mengkonstruk Pengetahuan."

Darmawan, D. (2014). "Pengembangan E-Learning: Teori dan Desain”.Remaja Rosdakarya.

Divayana, D. G. H. (2017). "Evaluasi Pemanfaatan E-Learning di Universitas Teknologi Indonesia Menggunakan Model CSE-UCLA”.Jurnal Cakrawala Pendidikan, 36(2):280-89.

Dwi, A. P., Pramudya, P., \& Sudarti, S. (2015). "Pengembangan Sistem E-Learning Untuk Meningkatkan Keterampilan Berpikir Kritis Mahasiswa Pendidikan Fisika".Jurnal Fisika Indonesia, 19(55):45-48.

Florida, N., López, C., \& Pocomucha, V. (2012). "Core View Metadata, Citation and Similar Papers at Core.Ac.Uk", 2(2):35-43. 
Gunawan, F.I, \& Sunarman, S.G. (2017). "Pengembangan Kelas Virtual dengan Google Classroom dalam Keterampilan Pemecahan Masalah (Problem Solving) Topik Vektor pada Siswa SMKuntuk Mendukung Pembelajaran".Prosiding Seminar Nasional Etnomatnesia, 340-48.

Hartanto, W. (2016). "Penggunaan E-Learning Sebagai Media Pembelajaran”.Jurnal Pendidikan Ekonomi, 10(1):1-18.

Hikmat, E.H, Aldim, A., \& Irwandi, I. (2020). "Efektivitas Pembalajaran Daring Selama Masa Pandemi Covid-19: Sebuah Survey Online".Digital Library, UIN Sunan Gunung Djati, Bandung.

Ibrahim, N. (2019). "ICT untuk Pendidikan Jarak Jauh".Jurnal Teknodik.

Jalaluddin, J.(2020). "Penguatan Pendidikan Karakter Berbasis Pancasila pada Siswa di Era Revolusi Industri 4.0", (1):84-95.

Mayang, M.(2021). "Personal Learning Environment Bersinergi dengan Teknology Pedagogic Content Knowledge terhadap Keterampilan Proses Sains", 6(1):72-81.

Meilia, M.\& Murdiana, M. (2019). "Pendidik Harus Melek Kompetensi dalam Menghadapi Pendidikan Abad Ke-21”.Al Amin: Jurnal Kajian Ilmu Dan Budaya Islam.

Moore, Joi L., Dickson-Deane, C., \& Galyen, K. (2011). "E-Learning, Online Learning, and Distance Learning Environments: Are They the Same?" Internet and Higher Education.

Mustofa, M.I, Chodzirin, M., \&Sayekti, L.(2019). "Formulasi Model Perkuliahan Daring sebagai Upaya Menekan Disparitas Kualitas Perguruan Tinggi (Studi terhadap Website pditt.belajar.kemdikbud.go.id)".Walisongo Journal of Information Technology, 1(2):151-60.

Pertiwi, U.D., Atanti, R.D., \&Ismawati, R. (2018). "Pentingnya Literasi Sains Pada Pembelajaran IPA SMP Abad 21".Indonesian Journal of Natural Science Education (IJNSE).

Rosiyanti, H. \&Muthmainnah, R.N. (2018). "Penggunaan Gadget Sebagai Sumber Belajar Mempengaruhi Hasil Belajar Pada Mata Kuliah Matematika Dasar".FIBONACCI: Jurnal Pendidikan Matematika dan Matematika, 4(1):25.

Rozalia, M.F. (2017). "Hubungan Intensitas Pemanfaatan Gadget Dengan Prestasi Belajar Siswa Kelas V Sekolah Dasar”.Jurnal Pemikiran dan Pengembangan Sekolah Dasar (JP2SD), 5(2):722.

Sudatha, I. G. W., Parmiti, D. P., \& Simamora, A.H. (2020). "Pengelolaan Sumber Belajar Digital Untuk Meningkatkan Pembelajaran Daring”.Proceeding Senadimas Undiksha, 1585-89.

Syaparuddin, S., Meldianus, M, \& Elhami, E. (2018). "Strategi Pembelajaran Aktif dalam Meningkatkan Motivasi Belajar PKn Peserta Didik”.Jurnal Pendidikan Guru Sekolah Dasar.

Yazdi, M. (2012). "E-Learning Sebagai Media Pembelajaran Interaktif Berbasis Teknologi Informasi".Jurnal Ilmua Foristek. 2(1):143-52. 